IZA DP No. 10166

Settling for Academia? H-1B Visas and the Career Choices of International Students in the United States

Catalina Amuedo-Dorantes

Delia Furtado

August 2016

Forschungsinstitut zur Zukunft der Arbeit Institute for the Study of Labor 


\title{
Settling for Academia? \\ H-1B Visas and the Career Choices of \\ International Students in the United States
}

\author{
Catalina Amuedo-Dorantes \\ San Diego State University \\ and IZA \\ Delia Furtado \\ University of Connecticut \\ and IZA
}

Discussion Paper No. 10166

August 2016

IZA

P.O. Box 7240

53072 Bonn

Germany

Phone: +49-228-3894-0

Fax: +49-228-3894-180

E-mail: iza@iza.org

Any opinions expressed here are those of the author(s) and not those of IZA. Research published in this series may include views on policy, but the institute itself takes no institutional policy positions. The IZA research network is committed to the IZA Guiding Principles of Research Integrity.

The Institute for the Study of Labor (IZA) in Bonn is a local and virtual international research center and a place of communication between science, politics and business. IZA is an independent nonprofit organization supported by Deutsche Post Foundation. The center is associated with the University of Bonn and offers a stimulating research environment through its international network, workshops and conferences, data service, project support, research visits and doctoral program. IZA engages in (i) original and internationally competitive research in all fields of labor economics, (ii) development of policy concepts, and (iii) dissemination of research results and concepts to the interested public.

IZA Discussion Papers often represent preliminary work and are circulated to encourage discussion. Citation of such a paper should account for its provisional character. A revised version may be available directly from the author. 


\section{ABSTRACT \\ Settling for Academia? H-1B Visas and the Career Choices of International Students in the United States}

For the first time since the inception of the H-1B visa, yearly caps became binding in 2004, making it harder for most foreign-born students to secure employment in the United States. However, since the year 2000, institutions of higher education and related non-profit research institutes had been exempt from the cap. We explore how immigrant employment choices were impacted by the binding visa cap, exploiting the fact that citizens of five countries (Canada, Mexico, Chile, Singapore and Australia) had access to alternate work visas. Our estimates suggest that international students from $\mathrm{H}-1 \mathrm{~B}$ dependent countries became more likely to work in academic institutions if they graduated after 2004 than immigrants from the five countries with substitute work visas. Within academia, foreign-born graduates affected by the visa cap became more likely to work in a job unrelated to their field of study, while no such change occurred in the private sector -a finding consistent with the notion of workers "settling for academia." We conclude with an analysis of workforce compositional changes in the academic versus private sectors as a result of the binding visa caps.

JEL Classification: F22, J61, J68

Keywords: H-1B visas, foreign-born workers, academic market, United States

Corresponding author:

Catalina Amuedo-Dorantes

Department of Economics

San Diego State University

San Diego, CA 92182

USA

E-mail: camuedod@mail.sdsu.edu 


\section{Introduction}

Proponents of more open immigration policy often cite the ability of immigrants to address shortages of workers in specific fields. For example, the relationship between workers in STEM (Science, Technology, Engineering and Mathematics) fields and innovation and economic growth have led some policy makers to propose "stapling" green cards to the diplomas of noncitizens who earn advanced degrees in STEM fields from U.S. universities (Thibodeau 2016). Others have advocated special work visas for health care professionals to address the growing health care needs of an aging population. ${ }^{1}$ Critics of these occupation or industry specific visas worry that these policies would create perverse incentives in both the labor and educational markets. Are immigrants responsive to this type of policy? In this paper, we address this question by exploring how the binding H-1B visa cap for employment in the private sector after 2004 affected the career choices of non-U.S. citizens who studied in a U.S. college or university.

The H-1B visa was established within the 1990 Immigration and Nationality Act to allow U.S. employers to temporarily hire foreign-born workers in specialty, high-skill occupations. The work authorization is limited to the sponsoring employer and lasts for three years, with the possibility of a three-year renewal and the sponsorship of permanent residency (i.e. green card). The number of H-1B visas, which had been initially capped at 65,000 per year, was temporarily increased to 115,000 in 1999 and 2000, and further to 195,000 in 2001, 2002 and 2003. However, as part of the H-1B Visa Reform Act of 2004, the visa cap for bachelor's degrees was reinstated to 65,000 , with an additional 20,000 visas available for applicants with U.S. postgraduate degrees starting in 2005 (see Figure 1).

\footnotetext{
1 The H-1A visa category, established through the 1989 Immigration Nursing Relief Act to allow for temporary employment of foreign-born nurses, expired in 1995. The H-1C visa program, established through the Nursing Relief for Disadvantaged Areas Act of 1999, was directed toward nurses in hospitals located in designated "health professional shortage areas" serving a minimum share of Medicaid and Medicare patients. This program expired in 2009.
} 
In 2004, the reinstated lower H-1B visa cap became binding. Suddenly, it became significantly harder for most foreigners to secure legal employment in the for-profit private sector. There were, nonetheless, some exceptions. Under the American Competitiveness in the 21st Century Act of 2000 (AC21), non-profit institutions of higher education, along with other non-profit and government research institutions, ${ }^{2}$ were excluded from the cap. ${ }^{3}$ In addition, free trade agreements allowed citizens from five countries (Canada, Mexico, Chile, Singapore and Australia) to apply for close H-1B visa substitutes (Sparber and Kato 2010; Shih 2015). ${ }^{4}$ We examine if international students graduating on or after 2004 became relatively more likely to pursue an academic career if they were from a country without an H-1B substitute visa, than if they were from one of the five countries with other work visas available.

A prolific literature has provided either direct or indirect evidence of significant reductions in the number of high skilled immigrants working in the United States when the visas became scarce (e.g. Ghosh, Mayda, Ortega 2014; Peri, Shih, Sparber 2015). The bulk of that literature focuses on the impact of visa scarcity on U.S. firms and native-born workers' outcomes; nevertheless, several papers examine the effects on H-1B holders themselves. For example, Clemens (2013) shows that Indian programmers who come to the United States after winning the H-1B lottery earn wages six times higher than comparable workers who lose the

\footnotetext{
${ }^{2}$ For the remainder of the paper, we will generally use the term "academia" to refer to non-profit institutions of higher education, non-profit research institutes associated with a university, and government research institutions. More than 80 percent of the H-1B applications in this category are for academic institutions (Sparber 2015). We will use the term "private sector" to refer to all other employers.

${ }^{3} \mathrm{H}-1 \mathrm{~B}$ holders in academia need to apply for a new H-1B visa (subject to the cap) to switch to the private sector. Private sector H-1B holders must also apply for a new H-1B visa, but they are not subject to the cap a second time.

${ }^{4}$ First, the North American Free Trade Agreement created the TN (Trade NAFTA) visa for professionals from Canada and Mexico. Although the approved list of occupations is more restrictive than that of the $\mathrm{H}-1 \mathrm{~B}$, each occupation is associated with college degree holders. There is no limit to the number of TN visas that can be issued. Second, two free trade agreements signed by President Bush on September 3, 2003 created the H-1B1 program by setting aside up to 5,400 of the annual H-1B visas for citizens of Singapore and up to 1,400 for Chileans. Finally, a bill signed on May 11, 2005 established 10,500 annual E-3 visas for Australian professionals. The caps on E-3 and H-1B1 visas have never been reached (H-1B1 visas set aside for citizens of Singapore and Chile are subtracted from the overall $\mathrm{H}-1 \mathrm{~B}$ visa quota. Unused $\mathrm{H}-1 \mathrm{~B} 1$ visas are made available, as $\mathrm{H}-1 \mathrm{~B}$ visas, to citizens of other countries).
} 
lottery and stay in India. More recently, Sparber (2015) shows that wages on H-1B applications from the private sector (bound by the cap) increase after the yearly cap is reached, relative to wages on $\mathrm{H}-1 \mathrm{~B}$ applications from academic institutions (unbound by the cap). He interprets this result as evidence that workers with an $\mathrm{H}-1 \mathrm{~B}$ visa in the private sector are able to negotiate higher wages (at a different firm) once the competition has subdued.

We build on this literature by examining how visa scarcity affects whether collegeeducated immigrants, who first came to the United States on a student visa, pursue careers in academia or the private sector. Understanding how the binding H-1B visa cap impacts the employment choices of immigrants is the first and most important step in learning about its further impacts on natives. After all, any native impacts are, if anything, of second order. Immigrants are the target of the reinstated, lower and binding visa cap. Learning how immigrants react to the more restrictive work visa policy can inform about the effectiveness of this type of policy in steering labor towards specific sectors and needs. Given the crucial role played by academia in higher education and innovation, understanding how a binding $\mathrm{H}-1 \mathrm{~B}$ visa cap alters immigrants' career choices and, in turn, the sector's composition is essential.

Using a quasi-experimental approach, we find that a post-2003 graduation is associated with an 8.6 percentage point increased likelihood of working in academic institutions for the foreign born from countries impacted by the visa cap relative to those from countries with alternative visas. This general finding, which we find to be driven by STEM students, is robust to various changes to the composition of the control and treatment countries as well as several other changes to the sample and model specification.

We then explore the mechanisms through which $\mathrm{H}-1 \mathrm{~B}$ visa caps might be impacting the careers of international students in the United States. First, we consider whether students who 
would have otherwise prepared for a career in the private sector tailor their studies for a career in academia by pursuing post-graduate studies. Limiting our sample to international students who completed their BA's in the United States, we find no evidence of students from H-1B visabound countries becoming relatively more likely to pursue a post-graduate degree when visas became scarce. Second, we explore whether H-1B-dependent graduates might have become more likely to settle for job offers within academia following the reinstatement of the lower visa cap. We find that immigrants from countries impacted by the visa cap but employed in academia became more likely to work in a field outside their expertise. This relationship is not observed among workers in the private sector suggesting that the foreign born who were not able to secure employment in the private sector following the quota cut may have accepted job offers in unrelated fields within academia.

We conclude our analysis with an exploration of how visa restrictions affect the characteristics of immigrants working in different fields in the United States. Because the visas are awarded on a first-come first-served basis, successful applications for an October $1^{\text {st }}$ start day are generally submitted six months prior. In years with particularly high demand for visas, even applications submitted on the earliest possible day, April 1, are denied. ${ }^{5}$ Although fees for unsuccessful applications are returned, lawyers' fees cannot be recovered. The additional costs and uncertainty encountered by private sector firms considering hiring foreign nationals without substitute visas could induce these firms to only consider H-1B dependent candidates if they are exceptionally well-qualified or are paid significantly less compared to other candidates. ${ }^{6}$

\footnotetext{
${ }^{5}$ Since 2004, the visa cap was reached in the first week in six of the fourteen years. A lottery is used to determine which of the applications submitted at the same time are awarded visas. For fiscal year 2017, United States Citizenship and Immigration Services (USCIS) received over 236,000 petitions within the first week.

${ }^{6}$ By law, firms must pay H-1B workers the higher of either the "prevailing wage" in the company for the particular job in question or the prevailing wage for the occupation in the firm's geographic region. However, there are ways in which firms can circumvent these laws.
} 
To test this prediction, we examine whether the visa cut impacted the wages and the educational distribution of immigrants from $\mathrm{H}-1 \mathrm{~B}$ dependent countries relative to those from countries with substitute visas separately in the private sector and the academic sector. As might be expected given that the academic sector was not directly impacted by the visa cut, we find no statistically significant changes in academia. However, in the private sector, wages of $\mathrm{H}-1 \mathrm{~B}$ dependent immigrants increased more than wages of immigrants with access to substitute visas after the lower visa cap. These immigrants also became more likely to have a post-graduate degree. We interpret these results as further evidence that our estimates are actually measuring a causal impact of the quota change as opposed to labor demand shocks that happen to be specific to citizens of countries without substitute visas. Our wage findings also suggest that $\mathrm{H}-1 \mathrm{~B}$ dependent workers are not perfectly substitutable with other workers and that private sector firms are not abusing their increased bargaining power from the visa cut to substantially underpay their workers.

The remainder of the paper proceeds as follows. Section 2 provides a brief background of the literature. A description of our data is presented in Section 3. Section 4 follows with an explanation of our baseline model and identification strategy. Baseline results as well as robustness checks and evidence supporting our identifying assumptions are provided in Section 5. Tests for heterogeneous effects are discussed in Section 6, and Section 7 follows with an examination of the mechanisms through which visa caps impact career decisions. Section 8 completes the study with an analysis how the relative wage and educational attainment of immigrants dependent on the $\mathrm{H}-1 \mathrm{~B}$ visa changed as a result of the visa cut, both in academia and the private sector. Section 9 summarizes our findings and concludes. 


\section{Relevant Literatures}

The present study builds on two related literatures and their employed methodologies. The first explores the impact of graduating during a recession on long term economic outcomes (Altonji, Kahn and Speer 2016; Kahn 2010; Oreopoulos, van Wachter, and Heisz 2012). As discussed in Oreopoulos et al. (2012), Canadians who graduate from college during a recession start their careers at lower paying jobs. Although their earnings recover, mostly because they move to better paying firms, their earnings losses last an average of ten years and can even be permanent for certain groups. $^{7}$ The variation in attractiveness of different career choices across graduation years also has implications for the relative quality of workers in different fields depending on when they were hired. For example, teachers starting their careers during recessions are better at raising student test scores (Nagler, Piopiunik, West 2015).

In our paper, instead of examining the responsiveness of career trajectories to economic conditions at the time of graduation, we explore international students' responsiveness to $\mathrm{H}-1 \mathrm{~B}$ visa scarcity at the time of graduation. We also examine how the characteristics of $\mathrm{H}-1 \mathrm{~B}$ dependent workers hired during periods of visa scarcity changed relative to the characteristics of workers with $\mathrm{H}-1 \mathrm{~B}$ substitutes in both the private sector, where the quota applies, and the academic sector, where the quota does not apply. Because we do not observe entire employment histories, we can only measure the impact of visa scarcity at graduation on employment at the time of the survey. However, given that graduating in recessions has been found to have long run implications, it is not unreasonable to expect that graduating when visas are scarce also has long run implications.

\footnotetext{
${ }^{7}$ Using panel data on students as opposed to Oreopoulos et al.'s matched employer-employee data, Kahn (2010) finds more permanent impacts of graduating in a recession in the United States. In an analysis of more recent data, Altonji, Kahn and Speer (2016) again find persistent wage impacts of graduating during a recession with stronger initial earnings losses during the Great Recession than what would have been predicted from earlier economic downturns.
} 
The second group of studies upon which our analysis builds exploits the fact that immigrants from five countries have had alternative visas to the $\mathrm{H}-1 \mathrm{~B}$ allowing them to work in the United States (Kato and Sparber 2013 and Shih 2015). These alternate visas are not perfect substitutes for the H-1B. Most importantly, they are meant to be used for truly temporary stays; it is not straightforward for workers on these alternate visas to apply for a green card. That said, they do allow foreign nationals to work in the United States and can be renewed indefinitely. Figure 2 shows how immigrants from these five countries became more likely to use the substitute visas when the cap on the H-1B became binding. Note, in particular, how quickly Australians started using the E3 visa shortly after its introduction in 2005.

Exploiting this variation, Kato and Sparber (2013) show that the quality of students, as measured by SAT scores, pursuing an undergraduate degree in the United States decreased in response to binding $\mathrm{H}-1 \mathrm{~B}$ caps. They interpret this as evidence that the opportunity to work in the United States is a main motivation for high ability students' decisions to study abroad. When visas become scarce, these high ability students become less likely to pursue U.S. bachelor's degrees, whereas low ability students, who may not have ever intended to work in the United States, are less affected. In a related analysis using a similar identification strategy, Shih (2015) shows that the $\mathrm{H}-1 \mathrm{~B}$ visa cap cut had a negative impact on the number of students pursuing degrees in the United States. We examine whether international students from countries without substitute visas who graduated after the policy change became more likely to pursue careers in academia relative to those graduating either before the policy change or after the policy change if they originated from countries with access to alternative work visas.

By informing how the reinstatement of the lower $\mathrm{H}-1 \mathrm{~B}$ visa cap affects the career paths of foreign-born graduates from countries bound by the H-1B visa cap, our findings complement 
those from a growing literature exploiting the same visa-cap variation to examine the impacts of high-skilled immigrants on innovation and productivity. Using state panel data, Hunt and Gauthier-Loiselle (2010) show that increases in the share of foreign-born college graduates lead to increases in the number of patents per capita. In a similar vein, Kerr and Lincoln (2010) find that $\mathrm{H}-1 \mathrm{~B}$ admissions are associated with more patents by people with Indian and Chinese last names, without meaningful decreases in the number of patents by natives. Lastly, exploiting variation in H-1B visa caps in conjunction with the distribution of STEM workers across U.S. cities before the start of the H-1B program, Peri, Shih, and Sparber (2015) find that H-1B driven increases in STEM workers are associated with higher wages for native workers, especially highskilled natives. Their finding suggests that high skilled foreign-born workers, at least those in STEM fields where innovation is central, complement high skilled natives in production. Consistent with this assessment, Kerr, Kerr, and Lincoln (2015) find that firms hiring more skilled foreign workers also hire more native workers. These findings, however, are not without controversy. Comparing H-1B lottery winners and losers in fiscal years 2007 and 2008, Doran et al. (2014) find no evidence of differences in patenting within eight years of the lottery. They also find that lottery winning firms have lower wages and higher profits. ${ }^{8}$ We contribute to this literature on the effects of H-1B quota restrictions by considering impacts on the career choices of those requiring the visa, as opposed to the impacts on native workers and firms.

\section{Data and Descriptive Statistics}

We rely on data from the 2003, 2010 and 2013 National Survey of College Graduates (NSCG). The NSCG provides coverage of the nation's college-educated population as of the

\footnotetext{
${ }^{8}$ Using an identification strategy similar to the one in Kerr and Lincoln (2010), Ghosh et al. (2015) show that H-1B visa restrictions are associated with losses in average labor productivity, as well as with reductions in firm size and profits in a subset of firms that conduct R\&D and are heavy users of H-1B workers.
} 
survey reference date, and it includes information on demographics, educational attainment, degree field, and sector of employment, among other characteristics. Our sample consists of immigrants who first came to the United States on a student visa, ${ }^{9}$ graduated on or after 1993 , and were living and working in the United States at the time of the survey. Although studying in the United States is not a prerequisite for receiving an $\mathrm{H}-1 \mathrm{~B}$ visa, we focus on international students because we can identify a year that they might specifically be looking for a job in the United States.

Table 1A provides some basic employment and demographic characteristics of foreignborn college graduates according to whether they are from countries bound by the H-1B visa cap. While similar in age, foreign-born college-graduates from countries bound by the cap are more likely to be male, and black or Asian, than their counterparts from unbound countries. They are also more likely to be married. A significantly higher share has completed a master's or Ph.D., even though fewer had a mother with a college education than foreigners from nations unbound by the visa cap. Immigrants from countries with H-1B substitutes are slightly more likely to live in the East and West, and less likely to live in the North Central and Southern parts of the United States. Most importantly, a somewhat higher share of foreign-born college graduates from countries bound by the H-1B visa cap are employed in the non-profit higher education and research oriented sector (23 percent as opposed to 20 percent). ${ }^{10}$

Many of the aforementioned differences, such the fact that foreign-born collegegraduates from countries bound by the cap are more likely to be male, black or Asian, married or

\footnotetext{
${ }^{9}$ Of the H-1B visas awarded in 2012, thirty-five percent were transferring from a student visa (Ruiz 2013).

${ }^{10}$ We use the "EMTP" variable in the NSCG to measure employer type. Our variable is equal to one for people who are working at a two or four year college or university, a medical school, or a university affiliated research institute. While some government and for profit research employees may be exempt from the visa cap, we cannot distinguish which ones fit into this category from our dataset. Therefore, we chose to be conservative and assume that they were bound by the visa.
} 
more highly educated than their counterparts from unbound countries, were already present prior to the reduction in the $\mathrm{H}-1 \mathrm{~B}$ visa cap, as shown in Table $1 \mathrm{~B}$. Therefore, it is crucial to account for such differences in the analysis.

Before turning to the formal regression analysis, we start our examination of the H-1B visa cap cut using a graphical approach. Figure 3 displays the mean share of foreign-born college-graduates from countries bound and unbound by the H-1B visa, before and after the change in the cap. It is apparent how the share of foreign-born college-graduates going into nonprofit higher education or research institutions practically doubled for those originating from countries bound by the H-1B visa cap, whereas it hardly rose for their counterparts from nations unbound by the H-1B visa cap.

To assess the statistical significance of any $\mathrm{H}-1 \mathrm{~B}$ visa cap employment impacts, Table 2 displays the estimated change in the shares after the enactment of the visa cap among both foreign-born college-graduates from countries bound by the H-1B visa cap and from nations that are not. While the share of young college-graduates from countries bound by the H-1B visa cap rose by 15.4 percentage points following the enactment of the policy, the share of young collegegraduates from other nations going into academia stood practically unchanged. As a result, with the new policy, the share of foreign-born college-graduates going into non-profit higher education or research jobs rose by a statistically significant 14.8 percentage points, an 89 percent increase given that the average share employed in that sector among foreign-born workers from countries bound by the H-1B visa was 16.6 percent prior to the policy change. 


\section{Methodology}

While revealing, Figure 3 and the descriptive statistics in Table 2 fail to properly account for a wide range of factors potentially responsible for the found impact. As such, we proceed to more rigorously examine the impact of the policy by estimating the following benchmark model:

$$
Y_{i, c, g, t}=\alpha+\beta H 1 B_{c, g}+X_{i, t} \gamma+\delta_{c}+\delta_{g}+\delta_{t}+\varepsilon_{i, c, g, t}
$$

where $Y_{i, c, g, t}$ equals 1 if foreign-born student $i$ from country $c$ who graduated in year $g$ is employed in academia in year $t$, and 0 otherwise. While we would like to observe the sector of employment right after the student obtained her/his highest degree, such information is not available in our data set. It is possible that some students who were initially constrained by the visa cap, started working in academia only to switch to the private sector later on in their careers. In that case, our estimates constitute a lower bound of the initial visa cap effect. We note, however, that even the first students affected by the policy are observed less than ten years after graduation in our sample.

Our variable of interest, $H 1 B$, measures exposure to the restrictive $\mathrm{H}-1 \mathrm{~B}$ visa policy. It equals 0 for all individuals graduating before 2004. For those graduating starting in 2004, it equals one; except for: (1) Canadians, Chileans, Mexicans, and Singaporeans, for whom it continues to equal zero, and (2) Australians, for whom the alternative visas became available in 2005; therefore, the variable equals one for those graduating in 2004, but turns back to zero for those graduating starting in 2005. The main coefficient of interest, $\beta$, measures how the binding H-1B visa cap has impacted the likelihood of obtaining a job in the academic sector among H-1B dependent foreign students relative to students with substitute visas available.

The vector $X$ accounts for a number of individual level characteristics likely affecting employment choices, such as age, age squared, gender, field of expertise, marital status and 
highest educational degree. The analysis also includes fixed effects to capture idiosyncratic labor market characteristics by foreigners' country of origin $\left(\delta_{c}\right)$ and graduation year $\left(\delta_{g}\right)$. We also include year of the survey fixed effects to control for economy-wide changes in the labor market over time $\left(\delta_{t}\right)$. Because we use several NSCG surveys, we are able to separately identify the impact of graduation year and survey year. With this full set of fixed effects, we are able to account for differences in labor market opportunities by country of origin, for poor labor market opportunities faced by students graduating in certain downturn years, and for contemporaneous macroeconomic shocks, respectively (Altonji, Kahn and Speer 2016; Kahn 2010; Oreopoulos, van Wachter, and Heisz 2012; Böhm and Watzinger, 2015). Standard errors are clustered at the country of origin level.

\section{Did the H-1B Visa Cap Alter the Employment Choices of International Students?}

\subsection{Main Findings}

Table 3 presents some preliminary results using a number of model specifications that progressively add controls. In the first column, we show that adding the individual-level controls does not significantly change the difference-in-difference estimate from Table 2. Further incorporating region of residence fixed-effects does not have a substantial impact either. However, adding field of degree fixed effects reduces our estimated coefficient by about 13 percent. This may suggest that our estimated impacts are partially driven by changes in college major choices that are unrelated to visa policy. Alternatively, it may also be the case that students respond to visa scarcity by majoring in fields that are more employable in the academic sector. To be most conservative, in the last column, we show results from a model including field-specific time trends; thereby addressing any unobserved time-varying field characteristics that could potentially be driving employment choices, such as field-specific federal grants or 
state support to universities and research projects. Doing so further reduces the estimate by 22 percent. Overall, the results from the most complete model specification suggest that the H-1B visa cap raised the employment likelihood of $\mathrm{H}-1 \mathrm{~B}$ dependent foreigners in academic and research oriented jobs by 8.6 percentage points (51 percent). ${ }^{11}$

As for the remaining coefficients, we find that increases in age are associated with a lower employment likelihood in the academic sector, but the relationship reverses after age 27.5. Married immigrants appear less likely to go into academia compared to immigrants who are divorced, widowed, or never married. In contrast, graduates with a Ph.D. or professional degree are, respectively, 32 percentage points and 13 percentage points more likely to work in academia or in a research institution than their reference group with only a bachelor's degree. The impact is, not surprisingly, large in the case of graduates with a doctoral degree, since they are more likely to be geared to research and academia.

\subsection{Robustness Checks}

A potential criticism of the identification strategy being used is that unobserved factors, unrelated to the H-1B quota cut, might have induced international students from countries without substitute work visas to increasingly go into academia relative to their counterparts from countries with alternative work visas available. One example of such a factor might be changes in unobserved ability. Although we do not have any measures of IQ or results from standardized test scores in our data, we have parental education. Unfortunately, this information is missing for many observations, leading us to exclude it from the baseline model. Still, to gauge its potential role on our estimate, we first run our model using the sample with non-missing

\footnotetext{
${ }^{11}$ We checked whether this impact dies out over time. We did not find statistically significant evidence of this being the case, but we can only observe individuals for up to nine years after graduation. These results are available from the authors.
} 
information on the parental education variable, but not including the variable itself yet, in column (1) of Table 4. While the policy impact looks smaller, it is no different from the estimated coefficient in column (2), where we further add parental education to our model. Furthermore, none of the two estimates are statistically different from our estimate from Table 3. Therefore, we continue our analysis using the larger sample size.

Subsequently, we explore whether the findings are driven by the graduates in a dominant field, as is the case with computer science. In fiscal year 2010, about half of all H-1B recipients were in computer-related occupations (Wasem 2012; Kerr, Kerr, and Lincoln 2014). By 2012, the number had risen to over 70 percent (Kerr, Kerr, and Lincoln 2014). If all of our results are driven by computer science-related occupations, we might be concerned that country of origin specific demand shocks for computer scientists within academia are playing a role in determining the patterns we find in the data. According to the estimate in column (3) of Table 4, that is not the case.

We also experiment with altering the implementation year of the visa cap. The Department of Homeland Security (DHS) fiscal year starts in October of the prior calendar year. Graduates often apply for Optional Practical Training (OPT), which during the time period under consideration lasted one year. Therefore, we consider the impact that the reinstatement of the lower visa cap would have been if students graduating in May 2003 were included among those impacted by the visa caps from DHS's 2004 fiscal year. Doing so lowers the estimated impact from 8.6 to 7.3 percentage points, but the two estimates are not statistically different from each other.

Another potential concern with our identification strategy is that the foreign born in our control group (those from Canada, Mexico, Chile, Australia, and Singapore) might have 
experienced some shock, unrelated to H-1B visa policy, making them more likely to opt for nonacademic jobs at the time of the reinstatement of the lower visa cap. To address that possibility, we expand our control sample to include other workers that were not affected by the visa policy change. The first group includes Puerto Ricans and those from U.S. territories who, despite having a distinct mother tongue and culture while growing up, do not face the employment restrictions examined herein. The second group includes all U.S. natives, regardless of whether or not they were born in the mainland. As can be seen in columns 5 and 6 of Table 4, in both instances, we continue to find that the reinstatement of the lower $\mathrm{H}-1 \mathrm{~B}$ visa cap raised the employment likelihood of H-1B dependent foreigners in academic jobs by approximately 12 and 13 percentage points, correspondingly.

Finally, we examine whether the results are driven by foreign-born graduates from specific countries in the treatment group. China and India are the two countries of origin receiving the most $\mathrm{H}-1 \mathrm{~B}$ visas. In particular, two-thirds of all recipients of new $\mathrm{H}-1 \mathrm{~B}$ visas in 2012 were from India (Kerr, Kerr, and Lincoln 2014). The two countries were also undergoing rapid economic changes during this time period. If international students who would have, otherwise, chosen to work in the private sector in the United States returned back to these countries after graduation in recent years, the observed impact might have little to do with the change in visa policy. Likewise, Bulgaria and Romania joined the European Union in 2007. As a result, many of their nationals might have sought private-sector employment in Europe, as opposed to the United States, independently of the new visa policy change. To assess if the observed impacts are driven by foreigners from those nations, we experiment with dropping them from the sample. In columns (7) through (9) of Table 4, our estimated coefficients of 
interest remain statistically significant and are not much different from the one in the most complete specification in Table 3, despite the substantially smaller sample sizes.

\subsection{Identification Checks}

While the findings in Table 3 appear robust to the inclusion of various regression controls and to most sample composition changes, their validity is predicated on a number of assumptions. In what follows, we address these assumptions as well as other potential concerns and limitations with the analysis.

\section{i. $\quad$ Support for the Parallel Trends Assumption}

One of the main threats to our empirical approach is whether there existed differential trends in the propensity of opting for a job in academia among foreign-born non-citizens who graduated prior to 2004 from countries non-exempt from the H-1B visa cap and those from elsewhere. To investigate whether that was the case, we construct new indicators for those graduating during the years preceding the implementation of the H-1B visa cap (that is: in 2000, 2001, 2002 and 2003) and originating from a never-exempt country. We then include the placebo terms, along with the true policy indicator, in a model similar to equation (1). If the impact captured in Table 3 was pre-existing, we would expect the placebo terms to have a statistically significant coefficient in the same direction of the H-1B-visa cap impact in Table 3. The results of this test are documented in Panel A of Table 5. The estimated coefficients on the placebo terms are not statistically different from zero, thus signaling that the visa cap impact in Table 3 was not due to pre-existing differential trends. Furthermore, despite the inclusion of the placebo terms, the true policy term continues to be statistically significant and similar in magnitude (roughly 8 percentage points) to the final estimate in Table 3. 
To offer reassurance that the results are not driven by a longer trend prior to the implementation of the visa cap, we restrict our sample to those graduating during the pre-policy period, namely: 1993 through 2003. Then, we create a time trend for the period under consideration, and interact it with a so-called eligibility indicator (i.e. originating from a neverexempt country). Panel B in Table 5 displays the results from this exercise. Consistent with the parallel trends assumption, we find no evidence of a pre-existing trend driving our results as the estimated coefficient on the interaction term is not statistically different from zero.

Lastly, as another way to check whether there is an underlying tendency after 2004 for immigrants from non-exempt countries to pursue careers in academia for reasons unrelated to visa policy, we follow Sparber (2015) in limiting our sample to those who work for exempt employers, academic institutions and non-profit research institutes. If factors, other than the policy change, were making employment in colleges and universities increasingly attractive specifically to $\mathrm{H}-1 \mathrm{~B}$ dependent immigrants, we should see increased employment of these groups on college campuses relative to non-profit research institutes after the policy change. Panel $\mathrm{C}$ of Table 5 shows results from a model similar to our baseline model, but estimated using a sample of workers employed in a job that is not subject to the H-1B visa quota. The dependent variable is equal to one for those employed in a research institute, and is equal to zero for those employed in a college or university. The estimated coefficient on our variable of interest is not statistically significant from zero, a result which may be explained by our substantially smaller sample size. However, the very small and positive estimate on out variable of interest might be viewed as suggestive evidence that the observed impacts in our baseline model are not driven by a factor, unrelated to visa policy, which has made colleges and universities more attractive employers. 


\section{ii. $\quad$ Reverse Causality Concerns: Which Countries Are Bound by the H-1B Visa Cap?}

Another challenge to the proper identification of our policy impact stems from a potential non-random designation of countries with $\mathrm{H}-1 \mathrm{~B}$ visa substitutes. It seems unlikely that countries have $\mathrm{H}-1 \mathrm{~B}$ substitutes specifically because nationals from these countries were increasingly likely to work in the private sector after 2004. After all, some of the substitutes were created many years before 2004 and were small parts of large trade treaties. Nonetheless, to address the potential concern that these countries had $\mathrm{H}-1 \mathrm{~B}$ substitute visas for reasons related to future changes in career trajectories of nationals, we follow La Ferrara et al. (2012) and aggregate the data for the period preceding the visa cap implementation -namely, prior to 2004 . We then estimate the following model:

$$
\text { Eligibility }_{c}=\alpha+\beta Y_{c}+Z_{c} \delta+\varepsilon_{c} \text {, }
$$

where Eligibility $c_{c}$ equals zero for countries with substitute visas (Canada, Mexico, Chile, Australia, and Singapore) and equals one for all other countries; $Y_{c}$ is the average employment rate in academia of migrants from country $c$ prior to 2004; and $Z_{c}$ is a vector of controls used in our prior estimations (aggregated at the country-of-origin level over the pre-visa cap period) reflecting average country level characteristics prior to the implementation of the visa cap.

Table 6 displays the results from this exercise. If we do not account for any other characteristics of the foreign-born, we find a statistically significant inverse relationship between the share of citizens employed in academia and the likelihood of being from a country that is dependent on the $\mathrm{H}-1 \mathrm{~B}$ visa. This suggests that, if anything, immigrants from countries which would eventually be impacted by $\mathrm{H}-1 \mathrm{~B}$ restrictions were less likely to work in academia, as opposed to more. In any event, columns 2 and 3 of Table 6 show how, as soon as we account for basic demographic and educational characteristics of the foreign-born from the various countries 
of origin prior to 2004, the statistical significance disappears. As such, there seems to be no significant link between the likelihood of originating from a non-exempt visa cap nation and the employment rates in academia of foreign-born graduates prior to the implementation of the visa cap. Therefore, the selection of which nations are bound from the H-1B visa cap does not appear to have been correlated with the employment rate of their nationals in the academia sectors prior to the implementation of the cap.

\section{Heterogeneous Impacts}

Next we examine whether the H-1B visa cap has had heterogeneous impacts depending on the migrant's education and field of experience. We are specifically interested in whether the effect of the visa cap differed depending on whether immigrants were B.A. versus post-graduate degree (M.A., Ph.D. or professional degree) holders, as well as the specific pull of the policy in specific fields of specialization, such as Science Technology Engineering and Mathematics (STEM) fields.

Table 7 displays the estimated impacts of the H-1B visa cap on the likelihood of holding a job in academia in the above-mentioned scenarios. When we split the sample by education, the coefficient of interest is not statistically significant in either the BA only sample or the postgraduate degree sample. Hence, our results do not appear to be entirely driven by holders of post-graduate degrees.

We next consider whether H-1B dependent students in STEM fields exhibit a higher tendency to pursue careers in academia when $\mathrm{H}-1 \mathrm{~B}$ visas become scarce. Prior research has shown that half of long-run U.S. productivity growth can be attributed to scientists and engineers (Jones 2005) suggesting that a possible intention of the academic exemption from the H-1B cap was to retain the brightest minds in STEM fields. According to the estimates in Table 7, the 
reinstatement of the lower H-1B visa cap increased the likelihood of holding academic or research jobs among graduates in STEM fields by close to 9.6 percentage points (34.5 percent). In contrast, the policy had no statistically significant impact on the likelihood of pursuing a career in academia among graduates in non-STEM fields. Regardless of whether this was the original intent of the exemption, we can conclude that the policy successfully contributed to the retention within academia of foreign-born U.S. graduates in STEM fields.

\section{Mechanisms}

There are several mechanisms through which H-1B visa caps may influence career trajectories of international students graduating from U.S. colleges and universities. One potential mechanism is that, mindful of the difficulty of securing a work visa, international students tailor their educations to prepare themselves for careers in academia when it becomes more difficult to work in the private sector. To explore this possibility, we keep a sample of international students who completed a bachelor's degree in the United States. We then examine whether those affected by the visa cap (because they are from countries without H-1B alternatives and they completed their bachelor's degree after the cap became binding) are relatively more likely to pursue a post-graduate degree (master's, doctoral, or professional degrees).

The first column of Table 8 shows that students in this sample did not become significantly more likely to pursue a post-graduate degree as a result of the visa cap. On the contrary, they became less likely to pursue a higher degree. This result is consistent with Kato and Sparber's (2013) finding that H-1B scarcity is associated with declines in the quality (as measured by SAT scores) of students pursuing undergraduate degrees in the United States. If after the policy change, international undergraduate students from $\mathrm{H}-1 \mathrm{~B}$ dependent countries 
have lower SAT scores on average, they might become less likely to pursue graduate degrees. Another potential explanation is that graduate study in the United States is costly, as measured by direct tuition fees and foregone income. This investment might only make sense if students are reasonably confident that they will be able to recoup these costs via higher future U.S. wages. When H-1B visas become scarce, students dependent on these visas may find it less optimal to make the investment.

Next, we examine the possibility that, faced with scarce visa opportunities, immigrants who might otherwise pursue careers within the private sector opt, instead, for jobs within academia where visas are unrestricted. The NSCG asks respondents whether they are working in a field outside the one in which they earned their highest degree. ${ }^{12}$ Therefore, we can easily assess if, following the reinstatement of the visa caps, immigrants working in academia became more likely to be working in a field outside of their degree than their counterparts in the private sector. The last columns of Table 8 show that, while foreign-born graduates in the private sector are much more likely to work outside of their field than those working in academia, those immigrants impacted by the visa restrictions were no more likely to work outside of their field than those who were not impacted if they managed to acquire jobs in the private sector. In contrast, within academia, immigrants affected by the visa cap were more likely to work outside of their field. A potential demand side explanation of this result is that academic institutions became less particular when making job offers. However, that seems unlikely given that policy change did not directly affect their ability to hire candidates regardless of country of origin. A more likely explanation is that high ability job-seekers from $\mathrm{H}-1 \mathrm{~B}$ dependent countries became more likely to accept job offers within academia for jobs that were not perfect fits for their level

\footnotetext{
${ }^{12}$ The question in the survey is "To what extent was your work on your principal job related to your highest degree? Was it a) closely related, b) somewhat related, or c) not related". Our variable for working in a field outside degree takes a value of one for respondents who answered "somewhat related" or "not related".
} 
of expertise. If these candidates were of sufficiently high ability, academic institutions would have been willing to hire them despite their degrees being in different fields.

Another potential mechanism driving our results is that the foreign-born interested in pursuing careers in the private sector may simply return to their home countries if they are unable to receive $\mathrm{H}-1 \mathrm{~B}$ visas in the private sector. This alone would imply that immigrants who remain in the United States are more likely to be employed in academia. Unfortunately, because we only have data on the immigrants who remain in the United States, we cannot directly test for this possibility. ${ }^{13}$ Therefore, while we cannot assess the role played by return migration, there is suggestive evidence that some international students do "settle for academia" in response to visa scarcity.

\section{Compositional Changes in the Academic and Private Sector Workforces}

Thus far, our findings suggest that the lowering of the H-1B visa cap increased the share of foreign-born workers from countries bound by the H-1B visa cap in academia when compared to foreign-born workers from other nations. To conclude our analysis, we examine how the skill composition of foreign-born workers changed differentially by sector in response to the 2004 policy, using wages as our primary measure of skill.

From a theoretical perspective, if labor markets are competitive, then a policy limiting labor supply to one sector, but not the other, should result in higher equilibrium wages in the constrained sector and lower wages in the unconstrained sector. Our identification strategy does

\footnotetext{
${ }^{13}$ Nonetheless, we did attempt to indirectly provide evidence of return migration by testing whether our results were stronger for immigrants who might be less likely to want to return to their home countries. We did not find this to be the case. As shown in Table 4, excluding countries experiencing important economic transformations during the time period in question (such as China, India and some entering European Union members) that might have induced more return migration, does not seem to change our estimates. In addition, we have examined whether immigrants from poorer countries, whom the literature has found to be more likely to stay in the United States after graduation (Grogger and Hanson 2013), became more likely to pursue academic careers when the visa caps became binding. Again, we did not find evidence of that being the case. These results are available upon request.
} 
not allow us to test for these changes by sector because equilibrium wages should not differ by whether the workers require limited visas. Labor restrictions should impact all workers in the same market. ${ }^{14}$ However, we can use differential wage changes to draw inferences about how selection into the different types of occupations changed as a result of the policy.

As discussed in the Introduction, the binding visa quota made it significantly more difficult for private sector firms to hire H-1B dependent workers. In most years following the reinstatement of the lower visa cap, firms had to submit applications exactly six months before the earliest possible start date. Even then, the application may not win the lottery, with subsequent monetary and times costs from interviewing and making a job offer, not to mention any lawyer fees involved in submitting the H-1B application. The additional uncertainty and planning associated with hiring a foreign national requiring a quota-limited visa may induce firms to only consider $\mathrm{H}-1 \mathrm{~B}$ dependent workers if they are exceptionally qualified or accept significantly lower wages.

Since wages might be considered a measure of productivity within the firm (either because of higher skill levels of workers or better quality job match), we can learn about changes in the productivity of workers of different types hired into the academic and private sector work forces by comparing wages of $\mathrm{H}-1 \mathrm{~B}$ dependent workers to those with substitute visas, before and after the lower visa caps became binding. In addition, exploring wage changes surrounding the reinstatement of the lower visa cap can help us in various ways.

First, it can help us gauge the validity of our employment findings. If the flow of H-1B dependent workers into academia was driven by an unobserved demand shock in 2004 specific to these workers, as opposed to by the reinstatement of the lower visa cap, we would expect the

\footnotetext{
${ }^{14}$ We could compare wages in the academic sector relative to the private sector before and after the policy change. But given the many changes that both sectors might have incurred during that time frame, we would not feel comfortable attributing any differences to the visa policy change.
} 
wages of $\mathrm{H}-1 \mathrm{~B}$ dependent workers to be higher than those of workers with substitute visas in academia (and/or lower in the private sector). In contrast, the reinstatement of the lower visa cap should not result in any relative wage changes by country of origin in the academic sector since this sector is exempt from the quota. In the private sector, where only the very highly qualified H-1B dependent workers might have been able to find employment, H-1B dependent worker wages might be higher in accordance to their higher qualifications, or lower if they paid significantly less than other workers.

Wage differentials can also inform about the substitutability between the foreign born who are $\mathrm{H}-1 \mathrm{~B}$ dependent and their non-H-1B dependent counterparts. If workers from different countries are perfect substitutes for each other, an employment restriction on workers from a particular origin should simply lead employers to hire workers from non-H-1B dependent countries, having little impact on wages in a particular sector. In contrast, if some of the workers requiring the limited visas are difficult to substitute with other workers, the reduction in the visa cap should result in substantial wage differentials. In this vein, using data on wage offers along with the specific date that the H-1B application process started, Sparber (2016) conducts an indirect test of the substitutability between workers by comparing wage offers in the private sector after the quotas on $\mathrm{H}-1 \mathrm{~B}$ work permits have been met, to offers made in the academic sector. He finds that private sector wage offers increase quite substantially after H-1B quotas are reached, suggesting that $\mathrm{H}-1 \mathrm{~B}$ workers are not perfectly substitutable with other workers. $^{15}$

A final argument for examining the impact of the policy change on wages is to gauge if H-1B workers are paid below market wages as a means to offset their potentially higher hiring

\footnotetext{
${ }^{15}$ In the private sector, firms are restricted to candidates who already have H-1B status. In the academic sector, any candidate can be hired throughout the year.
} 
cost. As a first step in applying for an H-1B visa, employers must attest on the Labor Condition Application (LCA) that they will pay a wage not lower than the higher of: (i) the wages paid to all other employees with similar experience and qualifications in the specific firm, or (ii) the prevailing wage level for the occupational classification. However, in practice, it is difficult to enforce this regulation. By examining wage impacts of the quota change in the private sector, we can gain further insight into whether firms pay lower wages to employees requiring the scarce visas or whether they restrict their H-1B hires to the most highly qualified candidates, paying them wages reflective of their higher productivity.

To examine wage compositional changes, we estimate a model similar to equation (1) separately in the private and academic sectors using the log of yearly wage payments as the dependent variable. Note that, because of the inclusion of graduation year and year of the survey fixed effects in the model, we are not identifying any equilibrium wage impacts of quota-induced labor supply shocks. As pointed out earlier, the latter would impact all workers regardless of their need for scarce visas. Instead, we consider whether, after the policy change, workers requiring the scarce visas had higher wages than workers with $\mathrm{H}-1 \mathrm{~B}$ substitutes. Additionally, our estimates should not be viewed as causal effects of the policy change on people's wages but, rather, as indicative of the types of workers that were able to secure employment in each sector after the visa quota cut.

Results in Table 9 show that the visa quota cut did not result in any statistically significant change in relative wages in the academic sector. However, workers requiring the scarce visas in the private sector were paid substantially more after the visa cut than workers with $\mathrm{H}-1 \mathrm{~B}$ substitutes. In the private sector, the reduction in $\mathrm{H}-1 \mathrm{~B}$ visas was associated with a 31 percent increase in the yearly earnings (in 2013 dollars) of foreign-born workers from 
countries bound by the $\mathrm{H}-1 \mathrm{~B}$ visa cap relative to those with substitute visas. This finding is supportive of the identification strategy used throughout our analysis. The observed "impact" on earnings is not consistent with an increase in demand in the academic sector (or with a decrease in demand in the private sector) for the foreign-born graduates requiring scarce $\mathrm{H}-1 \mathrm{~B}$ visas. Secondly, the wage results are also consistent with the findings in Sparber (2016), who concludes that workers dependent on the restricted H-1B visas are not perfectly substitutable with other workers. Finally, the earnings results also suggest that firms are abiding by their attestations on the LCAs -that is, they do not seem to respond to $\mathrm{H}-1 \mathrm{~B}$ restrictions by paying $\mathrm{H}-$ 1B workers less relative to other workers.

While we do not perfectly observe skill, we can examine changes in the educational gradient of foreign-born workers from countries bound by the $\mathrm{H}-1 \mathrm{~B}$ visa cap after the latter was cut in both the academic and private sectors to gauge if private sector firms become more selective when hiring foreign-born that require scarce H-1B visas. As shown in the last panels of Table 9, H-1B dependent workers in the private sector became more likely to have a postgraduate degree after the quota became binding. No such change occurred within academia. This finding, while also consistent with the availability of an additional 20,000 H-1B visas for foreign-born workers who had completed a graduate degree in the United States, supports the notion that private sector firms became more selective when hiring candidates requiring an $\mathrm{H}-1 \mathrm{~B}$ visa as the latter became scarcer.

\section{Summary and Conclusions}

Overall, our analysis informs on various impacts of the more restrictive immigration policy pertaining to high-skill immigrants. Using several years of data from the NSCG, we examine whether immigrants from countries without $\mathrm{H}-1 \mathrm{~B}$ substitute visas are more likely to 
work in academic institutions if they graduated after the H-1B quota cut in 2004, relative to the countries with H-1B substitutes. We find that, indeed, they are. These results are robust to changes in the composition of the control and treatment groups, as well as to changes in our control variables. We also address common threats of difference-in-difference analyses. For example, we test for differential likelihoods of pursuing careers in academia before the H-1B visa quota became binding and find no evidence of this.

We then investigate the mechanisms through which $\mathrm{H}-1 \mathrm{~B}$ quota cuts increase the likelihood that the foreign born pursue careers in academia -at least, among those who remain in the United States. We do not find evidence of foreign-born graduates flocking into post-graduate programs in order to improve their employment chances in academia. However, we find suggestive evidence that some of the immigrants employed in the academic sector following the reinstatement of the $\mathrm{H}-1 \mathrm{~B}$ visa caps might have, otherwise, preferred to work in the private sector. As the visas became scarcer, immigrants without available substitutes for the $\mathrm{H}-1 \mathrm{~B}$ visa became more likely to work in a field outside of their degree if they worked in academia, but not if they worked in the private sector.

To conclude, we examine whether private sector firms became more selective when hiring $\mathrm{H}-1 \mathrm{~B}$ dependent workers after the H-1B visa quota became binding, relative to workers with substitute visas available. In the private sector, we find post-2004 graduation wage increases for the foreign-born relying on the scarce $\mathrm{H}-1 \mathrm{~B}$ visas, at the same time that the share of them with post-graduate degrees rose. No such pattern is found in the academic sector, where the costs of hiring a foreign-born worker did not change after the visa cut. The results not only give credence to our identification strategy, but also provide further support for the conclusion in the immigration literature that $\mathrm{H}-1 \mathrm{~B}$ dependent immigrants are not perfect substitutes for other 
types of workers. In addition, the findings suggest that, while firms may become more selective in their hiring decisions of foreign-born workers as the visas become scarce, they do not simply pay these workers substantially less in response to the increased firm bargaining power.

The likely intention of the higher education exemption from the H-1B visa cap was to retain (foreign) talent in the United States. This paper examines whether the binding H-1B cap, in conjunction with the academic exemption, results in changes in the intended career paths of the foreign-born. Learning how immigrants respond to this type of policy is crucial in understanding its role in steering labor toward specific sectors. To the extent that the policies target immigrant labor, any discussion regarding their potential impacts on natives inevitably begs for an understanding of how they impact immigrants in the first place. If, additionally, we consider the role of academia as a pillar of higher education and innovation, further attention to how changes in the H-1B visa policy affect its composition (and that of the private sector) is well warranted. 


\section{References}

Altonji, Joseph G., Lisa B. Kahn and Jamin D. Speer. 2016. "Cashier or Consultant? Entry Labor Market Conditions, Field of Study, and Career Success" Journal of Labor Economics, University of Chicago Press, vol. 34(S1), pages S361 - S401.

Böhm, M. J. and Watzinger, M. 2015. "The Allocation of Talent over the Business Cycle and its Long-term Effect on Sectoral Productivity" Economica. doi: 10.1111/ecca.12143

Clemens, Michael A. 2013. "Why Do Programmers Earn More in Houston Than Hyderabad? Evidence from Randomized Processing of US Visas" American Economic Review Papers \& Proceedings, 103(3), pages 198-202.

Ghosh, Anirban, Anna Maria Mayda and Francesc Ortega. 2014. “The Impact of Skilled Foreign Workers on Firms: An Investigation of Publicly Traded U.S. Firms" IZA Discussion Papers 8684, Institute for the Study of Labor (IZA).

Grogger, Jeffrey and Gordon H. Hanson. 2013. "Attracting Talent: Location Choices of Foreign-Born PhDs in the U.S”, NBER Working Paper No. 18780.

Hunt, Jennifer, and Marjolaine Gauthier-Loiselle. 2010. "How Much Does Immigration Boost Innovation?" American Economic Journal: Macroeconomics, 2(2): 31-56.

Jones, Charles I. 1995. Time series tests of endogenous growth models. Quarterly Journal of Economics 110, no. 2:495-525.

Kato, Takao and Chad Sparber. 2013. "Quotas and Quality: The Effect of H-1B Visa Restrictions on the Pool of Prospective Undergraduate Students from Abroad" The Review of Economics and Statistics, 95(1): 109-126.

Sari Pekkala Kerr \& William R. Kerr \& William F. Lincoln. 2014. "Firms and the Economics of Skilled Immigration" NBER Working Papers 20069, National Bureau of Economic Research, Inc.

Kahn, Lisa B. 2010. "The Long-Term Labor Market Consequences of Graduating from College in a Bad Economy" Labour Economics, 17(2): 303-16.

Kerr, Sari Pekkala, William R. Kerr, and William F. Lincoln. 2015. "Skilled Immigration and the Employment Structures of US Firms" Journal of Labor Economics 33.S1: S147-S186.

Kerr, William, and William Lincoln. 2010. "The Supply Side of Innovation: H-1B Visa Reforms and U.S. Ethnic Invention” Journal of Labor Economics 28(3): 473-508.

Oreopoulos, Philip, Till von Wachter, and Andrew Heisz. 2012. "The Short- and Long-Term Career Effects of Graduating in a Recession" American Economic Journal: Applied Economics, 4(1): 1-29. 
Peri, Giovanni, Kevin Y. Shih and Chad Sparber. 2015. "Foreign and Native Skilled Workers: What Can We Learn from H-1b Lotteries?” NBER Working Paper No. w21175.

Ruiz, N. G. 2013. “Immigration Facts on Foreign Students” Brookings Institution.

Shih, Kevin. 2015. "Labor Market Openness, H-1B Visa Policy, and the Scale of International Student Enrollment in the United States" Economic Inquiry. doi:10.1111/ecin.12250

Wasem, Ruth Ellen. 2012. "Immigration of Foreign Nationals with Science, Technology, Engineering, and Mathematics (STEM) Degrees" May. 
Figure 1: Official Cap and Number of H-1B Visas, 1990-2012

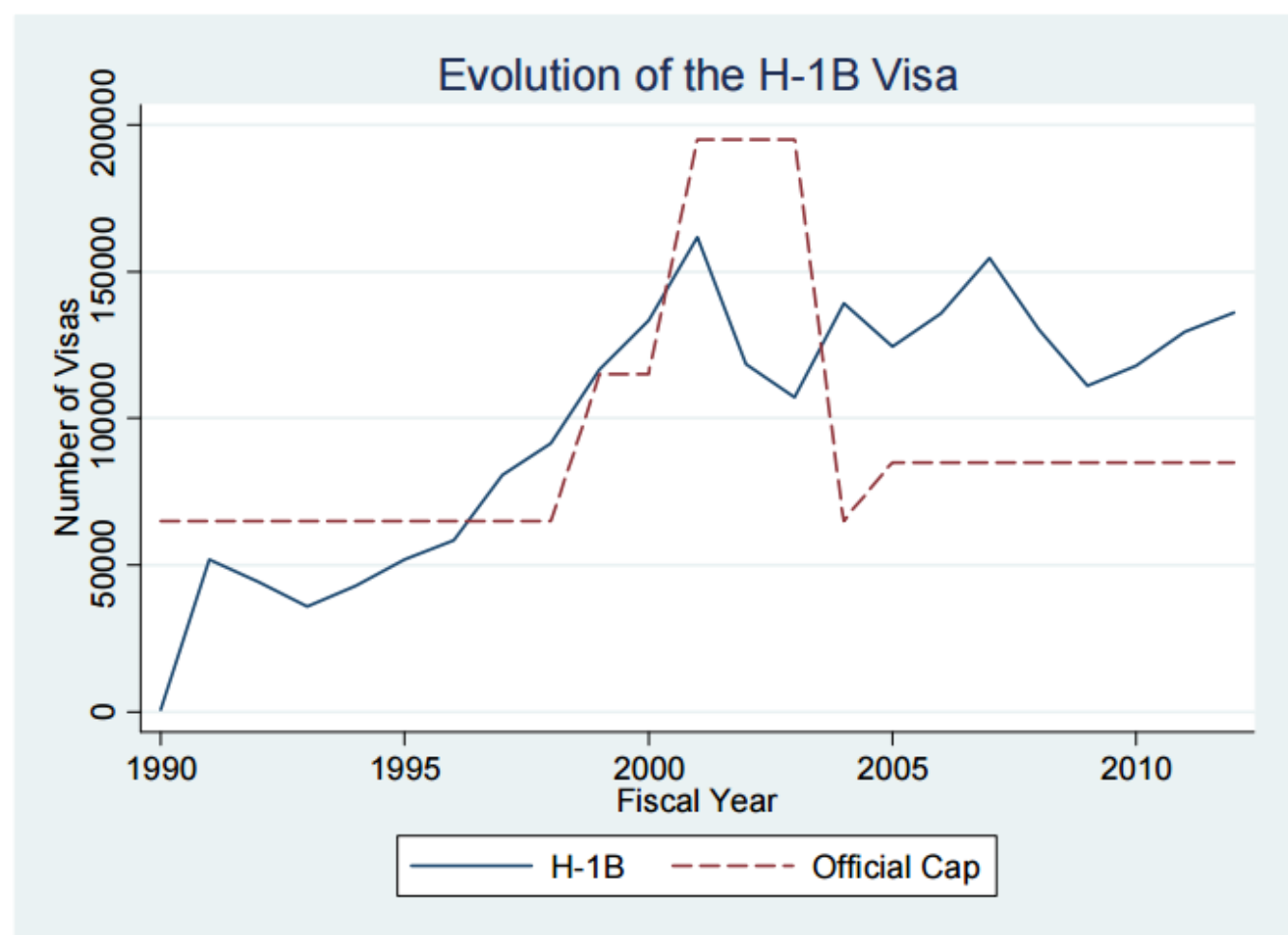

Note: The data on $\mathrm{H}-1 \mathrm{~B}$ visas and their cap are from the Department of State (2011)

Source: Kato, Takao and Chad Sparber (2013). 
Figure 2

\section{H-1B Usage by Control Countries}
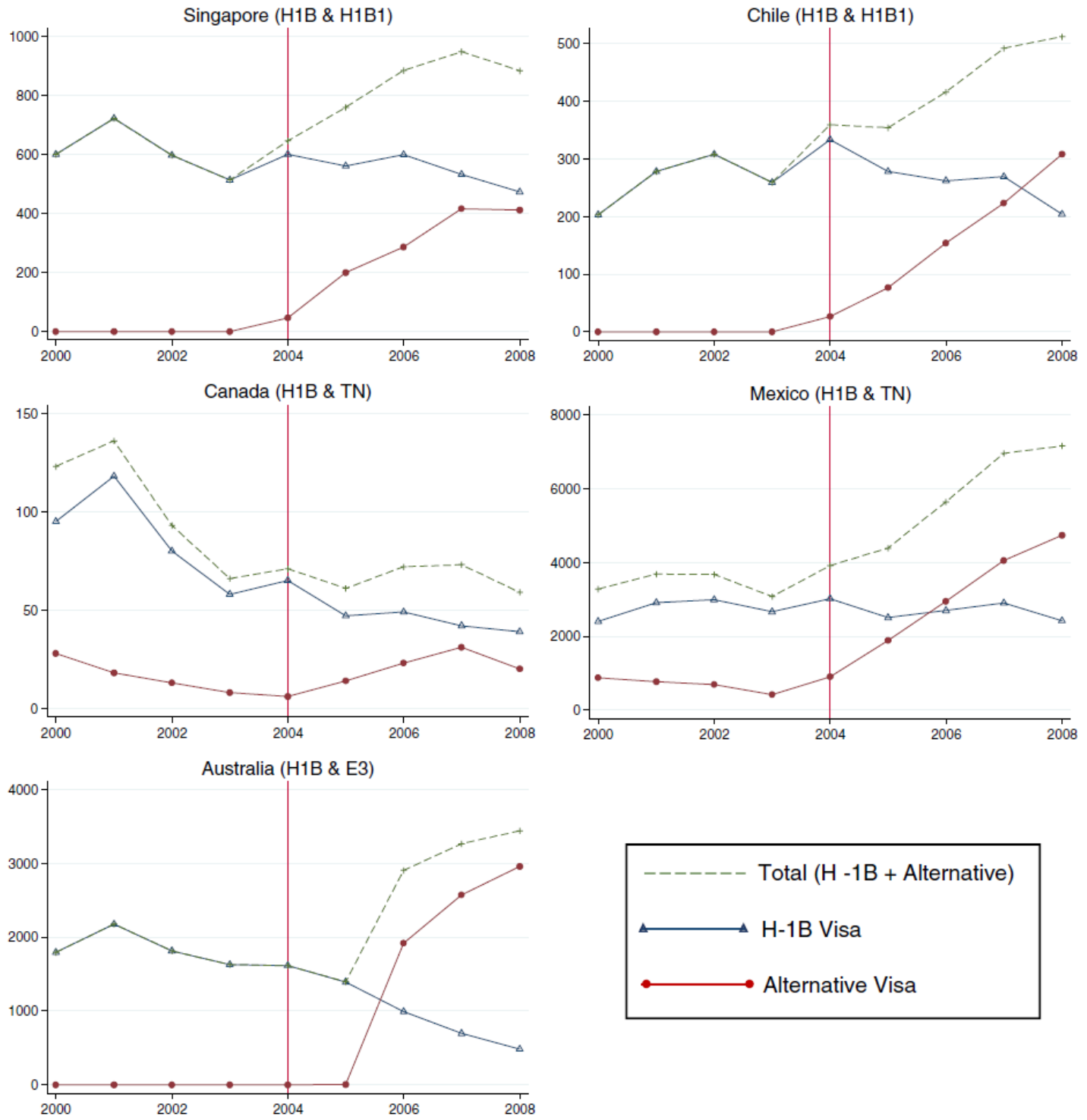

Note: The above set of figures displays H-1B visa usage, measured by visas issued to that country group, from 2000 to 2008 . Also displayed is visa usage of alternative visa classes for high skilled immigrants. These include the $\mathrm{H}-1 \mathrm{~B} 1$ visa for Singaporeans and Chileans, the TN visa for Canadians and Mexicans, and the E3 visa for Australians. Data come from the Department of State's Non-immigrant Visa Statistics (Department of State 2012).

Source: Shih (2015). 
Figure 3: Share of Foreign-born in Academia and Non-Profit Research Organizations by Graduation Year and Country of Origin

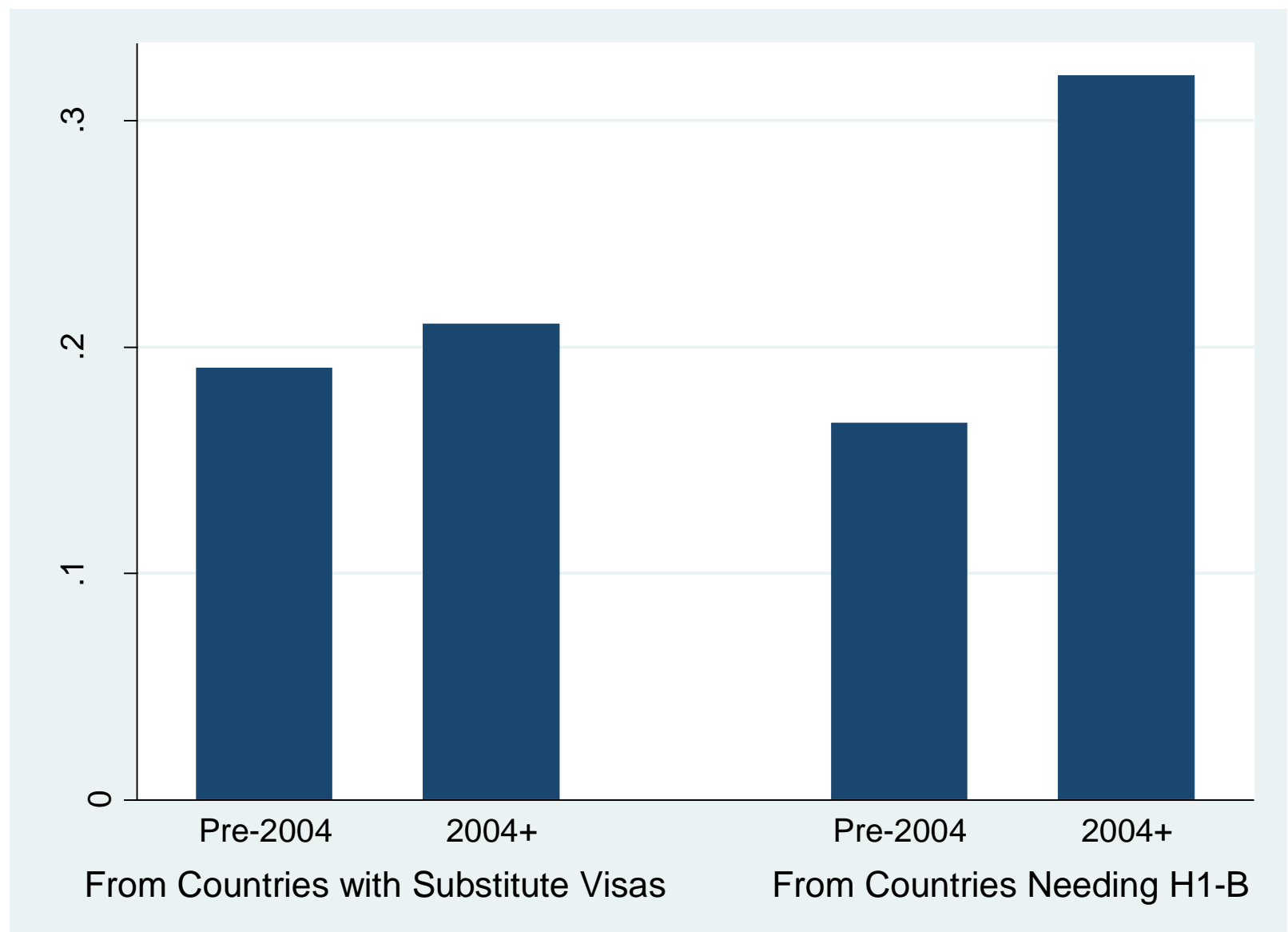

Source: Authors' tabulations using the NSCG data. 
Table 1A: Weighted Summary Statistics

\begin{tabular}{|c|c|c|c|c|}
\hline \multirow{2}{*}{$\begin{array}{l}\text { Sample } \\
\text { Statistic }\end{array}$} & \multicolumn{2}{|c|}{$\begin{array}{c}\text { Bound by H-1B Visa Cap } \\
(H 1 B=1)\end{array}$} & \multicolumn{2}{|c|}{$\begin{array}{c}\text { Not Bound by H-1B Visa Cap } \\
(H 1 B=0)\end{array}$} \\
\hline & Mean & S.D. & Mean & S.D. \\
\hline Employment in Academic and Research Jobs & 0.231 & 0.422 & 0.198 & 0.399 \\
\hline Age & 37.660 & 7.986 & 38.484 & 8.807 \\
\hline Male & 0.646 & 0.478 & 0.437 & 0.496 \\
\hline Married & 0.725 & 0.447 & 0.699 & 0.459 \\
\hline White & 0.232 & 0.422 & 0.535 & 0.499 \\
\hline Black & 0.087 & 0.282 & 0.004 & 0.063 \\
\hline Asian & 0.603 & 0.489 & 0.088 & 0.284 \\
\hline Hispanic & 0.073 & 0.260 & 0.300 & 0.459 \\
\hline B.A. Degree & 0.225 & 0.418 & 0.412 & 0.493 \\
\hline M.A. Degree & 0.504 & 0.500 & 0.368 & 0.483 \\
\hline Ph.D. Degree & 0.232 & 0.422 & 0.147 & 0.354 \\
\hline Professional Degree & 0.040 & 0.195 & 0.073 & 0.261 \\
\hline Year of Graduation (Highest Degree) & 2002 & 5.393 & 2002 & 6.098 \\
\hline College-educated Mother & 0.158 & 0.365 & 0.246 & 0.431 \\
\hline College-educated Father & 0.125 & 0.331 & 0.105 & 0.307 \\
\hline East & 0.235 & 0.424 & 0.253 & 0.435 \\
\hline North Central & 0.164 & 0.370 & 0.154 & 0.361 \\
\hline West & 0.285 & 0.451 & 0.320 & 0.467 \\
\hline South & 0.315 & 0.465 & 0.273 & 0.446 \\
\hline Observations & \multicolumn{2}{|c|}{9,282} & \multicolumn{2}{|c|}{546} \\
\hline
\end{tabular}

Notes: Authors' tabulations using data from foreign-born college graduates who came to the United States on a student visa and were interviewed in the 2003, 2010 and 2013 NSCG. 
Table 1B: Weighted Summary Statistics Pre-Policy Change

\begin{tabular}{lcccc}
\hline Sample & $\begin{array}{r}\text { Bound by H-1B Visa Cap } \\
(H \mathbf{B}=\mathbf{1})\end{array}$ & $\begin{array}{c}\text { Not Bound by H-1B Visa Cap } \\
(\boldsymbol{H 1 B}=\mathbf{0})\end{array}$ \\
\hline Statistic & Mean & S.D. & Mean & S.D. \\
\hline Employment in Academic and Research Jobs & 0.166 & 0.372 & 0.191 & 0.393 \\
Age & 40.258 & 7.131 & 39.927 & 7.333 \\
Male & 0.653 & 0.476 & 0.516 & 0.5 \\
Married & 0.816 & 0.388 & 0.769 & 0.422 \\
White & 0.242 & 0.428 & 0.592 & 0.492 \\
Black & 0.072 & 0.258 & 0.003 & 0.051 \\
Asian & 0.605 & 0.489 & 0.114 & 0.318 \\
Hispanic & 0.075 & 0.264 & 0.289 & 0.454 \\
B.A. Degree & 0.236 & 0.424 & 0.357 & 0.48 \\
M.A. Degree & 0.462 & 0.499 & 0.392 & 0.489 \\
Ph.D. Degree & 0.251 & 0.434 & 0.150 & 0.358 \\
Professional Degree & 0.051 & 0.22 & 0.100 & 0.301 \\
Year of Graduation (Highest Degree) & 1998 & 3.072 & 1997 & 2.669 \\
College-educated Mother & 0.221 & 0.415 & 0.136 & 0.343 \\
College-educated Father & 0.304 & 0.46 & 0.230 & 0.422 \\
East & 0.239 & 0.426 & 0.327 & 0.47 \\
North Central & 0.162 & 0.368 & 0.182 & 0.386 \\
West & 0.293 & 0.455 & 0.274 & 0.447 \\
South & 0.307 & 0.461 & 0.217 & 0.413 \\
Observations & & 5,512 & & 343 \\
\hline
\end{tabular}

Notes: Authors' tabulations using data from foreign-born college graduates who came to the United States on a student visa and were interviewed in the 2003, 2010 and 2013 NSCG. 
Table 2: Differences-in-Differences in the Share Employed in Academic or Non-profit Research Jobs

\begin{tabular}{|c|c|c|c|c|c|c|c|c|c|c|}
\hline & \multicolumn{4}{|c|}{ Immigrants Bound by H-1B Visa Cap } & \multicolumn{4}{|c|}{ Immigrants Not Bound by H-1B Visa Cap } & \multicolumn{2}{|l|}{ DD } \\
\hline & Pre-2004 & Post-2004 & DT & $\mathbf{N}$ & Pre-2004 & Post-2004 & DC & $\mathbf{N}$ & (DT-DC) & $\mathbf{N}$ \\
\hline Employment Share & $\begin{array}{c}0.166 \\
{[0.372]}\end{array}$ & $\begin{array}{c}0.320 \\
{[0.466]}\end{array}$ & $\begin{array}{c}0.154 * * * \\
(0.026)\end{array}$ & 9,282 & $\begin{array}{c}0.196 \\
{[0.397]}\end{array}$ & $\begin{array}{c}0.202 \\
{[0.403]}\end{array}$ & $\begin{array}{c}0.006 \\
(0.031)\end{array}$ & 546 & $\begin{array}{c}0.148 * * * \\
(0.038)\end{array}$ & 9,828 \\
\hline
\end{tabular}

Notes: Standard deviations are in brackets and standard errors, clustered at the country of origin level, are in parentheses. All regressions include a constant term. $* p<0.1 ; * *<<0.05 ; * * * p<0.01$. 
Table 3: Likelihood of Employment in Academic and Research Jobs

\begin{tabular}{|c|c|c|c|c|}
\hline Model Specification & (1) & $(2)$ & (3) & (4) \\
\hline Bound by H-1B Visa Cap & $\begin{array}{c}0.130 * * * \\
(0.044)\end{array}$ & $\begin{array}{c}0.127 * * * \\
(0.035)\end{array}$ & $\begin{array}{c}0.110^{* * * *} \\
(0.031)\end{array}$ & $\begin{array}{c}0.086^{* * * *} \\
(0.026)\end{array}$ \\
\hline Age & $\begin{array}{c}-0.064 * * * \\
(0.019)\end{array}$ & $\begin{array}{c}-0.057 * * * \\
(0.016)\end{array}$ & $\begin{array}{c}-0.056^{* * * *} \\
(0.016)\end{array}$ & $\begin{array}{c}-0.055^{* * *} \\
(0.015)\end{array}$ \\
\hline Age-squared & $\begin{array}{c}0.001 * * * \\
(0.000)\end{array}$ & $\begin{array}{c}0.001 * * * \\
(0.000)\end{array}$ & $\begin{array}{c}0.001 * * * \\
(0.000)\end{array}$ & $\begin{array}{c}0.001 * * * \\
(0.000)\end{array}$ \\
\hline Male & $\begin{array}{l}-0.019 \\
(0.018)\end{array}$ & $\begin{array}{l}-0.022 \\
(0.017)\end{array}$ & $\begin{array}{l}-0.012 \\
(0.014)\end{array}$ & $\begin{array}{l}-0.013 \\
(0.014)\end{array}$ \\
\hline Black & $\begin{array}{c}0.072 \\
(0.069)\end{array}$ & $\begin{array}{c}0.052 \\
(0.068)\end{array}$ & $\begin{array}{c}0.056 \\
(0.071)\end{array}$ & $\begin{array}{c}0.050 \\
(0.074)\end{array}$ \\
\hline Asian & $\begin{array}{c}0.020 \\
(0.067)\end{array}$ & $\begin{array}{c}0.015 \\
(0.066)\end{array}$ & $\begin{array}{c}0.008 \\
(0.063)\end{array}$ & $\begin{array}{l}-0.002 \\
(0.060)\end{array}$ \\
\hline Hispanic & $\begin{array}{l}-0.056 \\
(0.087)\end{array}$ & $\begin{array}{l}-0.057 \\
(0.089)\end{array}$ & $\begin{array}{l}-0.069 \\
(0.083)\end{array}$ & $\begin{array}{l}-0.064 \\
(0.078)\end{array}$ \\
\hline Married & $\begin{array}{c}-0.064 * * * \\
(0.015)\end{array}$ & $\begin{array}{c}-0.062 * * * \\
(0.013)\end{array}$ & $\begin{array}{c}-0.060^{* * *} \\
(0.013)\end{array}$ & $\begin{array}{c}-0.062 * * * \\
(0.013)\end{array}$ \\
\hline M.A. Degree & $\begin{array}{c}0.029 \\
(0.037)\end{array}$ & $\begin{array}{c}0.028 \\
(0.036)\end{array}$ & $\begin{array}{c}0.041 \\
(0.032)\end{array}$ & $\begin{array}{c}0.042 \\
(0.032)\end{array}$ \\
\hline Ph.D. Degree & $\begin{array}{c}0.372 * * * \\
(0.055)\end{array}$ & $\begin{array}{c}0.360 * * * \\
(0.053)\end{array}$ & $\begin{array}{c}0.318 * * * \\
(0.051)\end{array}$ & $\begin{array}{c}0.324 * * * \\
(0.050)\end{array}$ \\
\hline Professional Degree & $\begin{array}{c}0.150 * * * \\
(0.042)\end{array}$ & $\begin{array}{c}0.133 * * * \\
(0.038)\end{array}$ & $\begin{array}{c}0.124 * * * \\
(0.030)\end{array}$ & $\begin{array}{c}0.134 * * * \\
(0.033)\end{array}$ \\
\hline Graduation Year FE & $\mathrm{Y}$ & $\mathrm{Y}$ & $\mathrm{Y}$ & $\mathrm{Y}$ \\
\hline Country of Origin FE & $\mathrm{Y}$ & $\mathrm{Y}$ & $\mathrm{Y}$ & $\mathrm{Y}$ \\
\hline Survey Year FE & $\mathrm{Y}$ & $\mathrm{Y}$ & $\mathrm{Y}$ & $\mathrm{Y}$ \\
\hline Region of Residence FE & $\mathrm{N}$ & $\mathrm{Y}$ & $\mathrm{Y}$ & $\mathrm{Y}$ \\
\hline Field of Expertise FE & $\mathrm{N}$ & $\mathrm{N}$ & $\mathrm{Y}$ & $\mathrm{Y}$ \\
\hline Field of Expertise-Time Trend & $\mathrm{N}$ & $\mathrm{N}$ & $\mathrm{N}$ & $\mathrm{Y}$ \\
\hline Dependent Variable Mean & \multicolumn{4}{|c|}{0.229} \\
\hline Observations & 9,828 & 9,828 & 9,828 & 9,828 \\
\hline R-squared & 0.255 & 0.282 & 0.300 & 0.307 \\
\hline
\end{tabular}

Notes: $* p<0.1 ; * * p<0.05 ; * * * p<0.01$. Data are collapsed at the country-of-origin level. The regression includes a constant term. 
Table 4: Robustness Checks of the Likelihood of Employment in Academic and Research Jobs

\begin{tabular}{|c|c|c|c|c|c|c|c|c|c|}
\hline Model Specification & (1) & (2) & (3) & (4) & (5) & (6) & (7) & (8) & (9) \\
\hline Bound by H-1B Visa Cap & $\begin{array}{c}0.072 * * \\
(0.030)\end{array}$ & $\begin{array}{c}0.071 * * \\
(0.030)\end{array}$ & $\begin{array}{c}0.101 * * * \\
(0.022)\end{array}$ & $\begin{array}{c}0.073 * * \\
(0.031)\end{array}$ & $\begin{array}{c}0.118 * * * \\
(0.023)\end{array}$ & $\begin{array}{c}0.127 * * * \\
(0.028)\end{array}$ & $\begin{array}{c}0.074 * * \\
(0.029)\end{array}$ & $\begin{array}{c}0.085 * * * \\
(0.028)\end{array}$ & $\begin{array}{c}0.073 * * \\
(0.031)\end{array}$ \\
\hline Parental Education & $\mathrm{N}$ & Y & $\mathrm{N}$ & $\mathrm{N}$ & $\begin{array}{c}\mathrm{N} \\
\text { With Puerto }\end{array}$ & $\mathrm{N}$ & $\mathrm{N}$ & $\mathrm{N}$ & $\mathrm{N}$ \\
\hline Exclusions/Additions & $\begin{array}{l}\text { Parental } \\
\text { Education } \\
\text { Sample }\end{array}$ & $\begin{array}{l}\text { Parental } \\
\text { Education } \\
\text { Sample }\end{array}$ & $\begin{array}{c}\text { No } \\
\text { Computer } \\
\text { Science }\end{array}$ & $\begin{array}{l}1 \text { year } \\
\text { earlier to } \\
\text { allow for } \\
\text { OPT }\end{array}$ & $\begin{array}{l}\text { Ricans and } \\
\text { other US } \\
\text { territories as } \\
\text { Control }\end{array}$ & $\begin{array}{c}\text { Including All } \\
\text { Natives as } \\
\text { Control }\end{array}$ & No China & No India & $\begin{array}{l}\text { No Bulgaria, } \\
\text { China, India } \\
\text { or Romania }\end{array}$ \\
\hline Dependent Variable Mean & 0.231 & 0.231 & 0.234 & 0.229 & 0.185 & 0.0851 & 0.212 & 0.239 & 0.22 \\
\hline Observations & 9,626 & 9,626 & 8,260 & 9,828 & 11,747 & 101,967 & 7,717 & 7,684 & 5,471 \\
\hline R-squared & 0.306 & 0.306 & 0.316 & 0.307 & 0.303 & 0.119 & 0.326 & 0.325 & 0.356 \\
\hline
\end{tabular}

Notes: $* p<0.1 ; * * p<0.05 ; * * * p<0.01$. The regression includes a constant term, as well as the regressors, fixed-effects and time trends in the most complete specification of Table 3 . Standard errors are clustered at the country of origin level. 
Table 5: Falsification Tests Checking for Pre-existing Effects of the Policy

\begin{tabular}{|c|c|}
\hline Panel A: & $\begin{array}{c}\text { Full Sample } \\
\text { Likelihood of Employment in Academic and Research Jobs }\end{array}$ \\
\hline Bound by H-1B Visa Cap & $\begin{array}{l}0.072 * * \\
(0.025)\end{array}$ \\
\hline 1 Year Prior to Bound by H-1B Visa Cap & $\begin{array}{l}-0.155 \\
(0.135)\end{array}$ \\
\hline 2 Years Prior to Bound by $\mathrm{H}-1 \mathrm{~B}$ Visa Cap & $\begin{array}{l}-0.066 \\
(0.048)\end{array}$ \\
\hline 3 Years Prior to Bound by H-1B Visa Cap & $\begin{array}{l}-0.080 \\
(0.128)\end{array}$ \\
\hline 4 Years Prior to Bound by H-1B Visa Cap & $\begin{array}{c}0.023 \\
(0.068)\end{array}$ \\
\hline $\begin{array}{l}\text { Observations } \\
\text { R-squared }\end{array}$ & $\begin{array}{l}9,828 \\
0.307\end{array}$ \\
\hline Panel B: & $\begin{array}{c}\text { Pre-Policy Sample } \\
\text { Likelihood of Employment in Academic and Research Jobs }\end{array}$ \\
\hline Time Trend*Treated Country & $\begin{array}{l}-0.007 \\
(0.006)\end{array}$ \\
\hline Time Trend & $\begin{array}{l}-0.015 \\
(0.036)\end{array}$ \\
\hline $\begin{array}{l}\text { Observations } \\
\text { R-squared }\end{array}$ & $\begin{array}{l}5,855 \\
0.278\end{array}$ \\
\hline
\end{tabular}

\begin{tabular}{lc}
\hline Panel C: & $\begin{array}{c}\text { Full Samp } \\
\text { Bound by H-1B Visa Cap }\end{array}$ \\
& Likelihood of Employment in \\
Observations & 0.006 \\
R-squared & $(0.033)$ \\
\end{tabular}

Notes: $* p<0.1 ; * * p<0.05 ; * * * p<0.01$. The regression includes a constant term, as well as the regressors, fixed-effects and time trends in the most complete specification of Table 3. Standard errors are clustered at the country of origin level.

Pre-Policy Sample: Foreign-born who came with student visas and obtained their highest degree prior to 2004. 
Table 6: Assessing the Endogeneity of Country Eligibility (Dependent Variable: Likelihood of Being from a Treated Country)

\begin{tabular}{|c|c|c|c|}
\hline Model Specification & (1) & (2) & (3) \\
\hline Key Regressors & Baseline & Extended Controls & Plus FE \\
\hline Employment Rate in Academia/Research & $\begin{array}{c}-0.347 * * \\
(0.159)\end{array}$ & $\begin{array}{l}-0.278 \\
(0.238)\end{array}$ & $\begin{array}{l}-0.350 \\
(0.261)\end{array}$ \\
\hline Average Age & & $\begin{array}{l}-0.013 \\
(0.110)\end{array}$ & $\begin{array}{l}-0.001 \\
(0.116)\end{array}$ \\
\hline Average Age Squared & & $\begin{array}{c}0.000 \\
(0.001)\end{array}$ & $\begin{array}{c}0.000 \\
(0.001)\end{array}$ \\
\hline Share Male & & $\begin{array}{l}-0.006 \\
(0.165)\end{array}$ & $\begin{array}{c}0.033 \\
(0.176)\end{array}$ \\
\hline Share Black & & $\begin{array}{c}0.127 \\
(0.130)\end{array}$ & $\begin{array}{c}0.062 \\
(0.146)\end{array}$ \\
\hline Share Asian & & $\begin{array}{c}0.056 \\
(0.061)\end{array}$ & $\begin{array}{c}0.108 \\
(0.069)\end{array}$ \\
\hline Share Hispanic & & $\begin{array}{c}-0.114 \\
(0.089)\end{array}$ & $\begin{array}{c}-0.062 \\
(0.097)\end{array}$ \\
\hline Share Married & & $\begin{array}{c}-0.017 \\
(0.222)\end{array}$ & $\begin{array}{l}-0.006 \\
(0.252)\end{array}$ \\
\hline Share with a M.A. Degree & & $\begin{array}{c}0.265 \\
(0.191)\end{array}$ & $\begin{array}{c}0.200 \\
(0.214)\end{array}$ \\
\hline Share with a Ph.D. Degree & & $\begin{array}{c}0.309 \\
(0.204)\end{array}$ & $\begin{array}{c}0.290 \\
(0.229)\end{array}$ \\
\hline Share with a Professional Degree & & $\begin{array}{l}-0.315 \\
(0.435)\end{array}$ & $\begin{array}{r}-0.893 * * \\
(0.501)\end{array}$ \\
\hline Graduation Year FE & $\mathrm{N}$ & $\mathrm{N}$ & $\mathrm{Y}$ \\
\hline Survey Year FE & $\mathrm{N}$ & $\mathrm{N}$ & $\mathrm{Y}$ \\
\hline Region of Residence FE & $\mathrm{N}$ & $\mathrm{N}$ & $\mathrm{Y}$ \\
\hline Field of Expertise FE & $\mathrm{N}$ & $\mathrm{N}$ & $\mathrm{Y}$ \\
\hline $\begin{array}{l}\text { Observations } \\
\text { R-squared }\end{array}$ & $\begin{array}{c}156 \\
0.030\end{array}$ & $\begin{array}{c}156 \\
0.152\end{array}$ & $\begin{array}{c}156 \\
0.395\end{array}$ \\
\hline
\end{tabular}

Notes: $* p<0.1$; ** $p<0.05$; *** $p<0.01$. Data are collapsed at the country-of-origin level. The regression includes a constant term. 
Table 7: Heterogeneity Impacts

(Dependent Variable: Likelihood of Employment in Academic and Research Jobs)

\begin{tabular}{|c|c|c|c|c|}
\hline \multirow{2}{*}{$\begin{array}{l}\text { By: } \\
\text { Group: }\end{array}$} & \multicolumn{2}{|c|}{ Educational Attainment } & \multicolumn{2}{|c|}{ Field of Expertise } \\
\hline & B.A. & Post-Graduate Degree & STEM & Non-STEM \\
\hline Bound by H-1B Visa Cap & $\begin{array}{c}0.087 \\
(0.118)\end{array}$ & $\begin{array}{c}0.024 \\
(0.059)\end{array}$ & $\begin{array}{l}0.096 * \\
(0.051)\end{array}$ & $\begin{array}{c}-0.033 \\
(0.046)\end{array}$ \\
\hline Dependent Variable Mean & 0.154 & 0.226 & 0.278 & 0.125 \\
\hline Observations & 1,444 & 8,384 & 8,035 & 1,793 \\
\hline R-squared & 0.518 & 0.302 & 0.294 & 0.509 \\
\hline
\end{tabular}


Table 8: Channels through Which Visa Caps May Impact Career Paths

\begin{tabular}{lc|cc}
\hline \multirow{2}{*}{ Channels } & $\begin{array}{c}\text { Likelihood of Pursuing a } \\
\text { Post-Graduate Degree }\end{array}$ & \multicolumn{2}{c}{$\begin{array}{c}\text { Working Outside } \\
\text { Their Degree }\end{array}$} \\
\cline { 2 - 4 } & Foreign-Born with a U.S. B.A. & Academia & $\begin{array}{c}\text { Private } \\
\text { Sector }\end{array}$ \\
\hline Bound by H-1B Visa Cap & $\mathbf{- 0 . 2 6 6}^{*}$ & $\mathbf{0 . 0 5 3} * * *$ & -0.078 \\
& $\mathbf{( 0 . 1 2 8 )}$ & $\mathbf{( 0 . 0 1 9 )}$ & $(0.052)$ \\
Dependent Variable Mean & 0.575 & 0.041 & 0.100 \\
Observations & 2,140 & 2,976 & 6,852 \\
R-squared & 0.480 & 0.130 & 0.269 \\
\hline
\end{tabular}

Sample for Pursuing a Higher Education: Foreign-born who immigrated with an F1 visa, studied their BA in the United States and completed their highest degree on or after 1993.

Notes: All model specifications include a constant term, as well as the regressors and fixedeffects in the most complete specification of Table 3. Standard errors are clustered at the country of origin level. They are displayed in parentheses. $* p<0.1 ; * * p<0.05 ; * * * p<0.01$. 
Table 9: Changes in the Composition of Employment and Annual Pay in Academia and the Private Sector Following the H-1B Visa Cap

\begin{tabular}{|c|c|c|c|c|}
\hline \multirow{2}{*}{ Outcomes } & \multicolumn{2}{|c|}{ Log (Annual Pay) } & \multicolumn{2}{|c|}{$\begin{array}{c}\text { Likelihood of Employment for Foreign-born } \\
\text { with a Post-Graduate Degree }\end{array}$} \\
\hline & Academia & Private Sector & Academia & Private Sector \\
\hline Bound by H-1B Visa Cap & $\begin{array}{c}0.090 \\
(0.074)\end{array}$ & $\begin{array}{c}\mathbf{0 . 3 1 4} * * \\
(\mathbf{0 . 1 1 1})\end{array}$ & $\begin{array}{c}0.013 \\
(0.158)\end{array}$ & $\begin{array}{l}\mathbf{0 . 3 5 4} * * \\
(\mathbf{0 . 0 9 8})\end{array}$ \\
\hline Dependent Variable Mean & 3.667 & 4.268 & 0.839 & 0.738 \\
\hline $\begin{array}{l}\text { Observations } \\
\text { R-squared }\end{array}$ & $\begin{array}{l}2,969 \\
0.692\end{array}$ & $\begin{array}{l}6,824 \\
0.517\end{array}$ & $\begin{array}{l}2,976 \\
0.435\end{array}$ & $\begin{array}{l}6,852 \\
0.376\end{array}$ \\
\hline
\end{tabular}

Sample: Foreign-born who immigrated with an F1 visa and completed their highest degree on or after 1993.

Notes: All model specifications include a constant term, as well as the regressors and fixed-effects in the most complete specification of Table 3. Standard errors are clustered at the country of origin level. They are displayed in parentheses. $* p<0.1 ; * * p<0.05 ; * * * p<0.01$. 